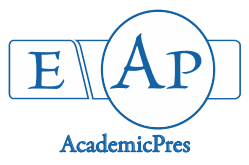

Orazizzdeh MR et al. (2020)

Notulae Scientia Biologicae 12(3):711-718

DOI: $10.15835 / \mathrm{nsb} 12310755$

Research Article

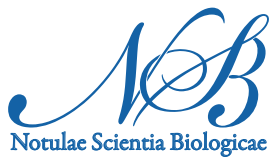

\title{
The effect of crop rotation on performance and qualitative characteristics of sugar beet
}

\author{
Mohammad R. ORAZIZADEH, Mostafa HOSSEINPOUR, \\ Parviz FASAHAT*
}

Sugar Beet Seed Institute (SBSI), Agricultural Research, Education and Extension Organization (AREEO), Karaj,

Iran; parviz.fasahat@gamil.com ("corresponding author); orazireza@yahoo.com; harm558@yahoo.com

\begin{abstract}
Sugar beet and sugarcane are two major crops for sugar extraction throughout the world. However, the sugar beet importance is not just about sugar production but it also plays an important role in crop rotation and increased productivity in various industries as well as livestock feed. In this study the long-term (2009-16) field trial effect of alfalfa (4 years)-winter wheat (1 year)-fallow (1 year)-sugar beet rotation on yield and quality parameters of sugar beet were evaluated for two consecutive rotations. The field trials were carried out at single location in Karaj, Iran, using randomized complete block design with four replications. Analysis of variance showed that the seasonal factors influenced different traits. In the first and second rotations, the root yield ranged from about 56.5 to 83.2 and 61.4 to $77.8 \mathrm{t} \mathrm{ha}^{-1}$, respectively with significant difference among cultivars in the first rotation. However, no significant difference was observed among both rotations in terms of root yield. Same results were obtained for sugar yield in both rotations which illustrates the stability of the abovementioned traits. Except for sugar content, significant difference was observed among other traits in both rotations. We show for the first time the effect of completing two rotation sequences on sugar beet performance and quality for decision making into a continual expansion/development of crop cultivation.

Keywords: crop rotation; field trial; preceding crop; root yield and quality; sugar beet

\section{Introduction}

Crop rotation has been known as an effective method for increasing soil fertility, reducing environmental pollution and also increasing the crop performance. Failure in the selection of proper rotation may result in organic matter loss as well as optimum soil condition, increased soil erosion and, finally the reduction of crop performance (Davis et al., 2012; Hemayati et al., 2017). Conventional farming was subjected to fundamental variations in terms of crop rotation practice. Nowadays, short-term rotations and flexible sequence cropping practices took classical crop rotation place as a response to economic demands and climate challenges (Stein and Steinmann, 2018). Furthermore, achievements in plant breeding and protection as well as technological advances led to the dominance of a few crops and as a result reduction in crop diversity in most agricultural farms (van Zanten et al., 2014; Hemayati et al., 2017). Global market fluctuations also encourage farmers to apply 2-3 years crop rotation instead of cyclical one (Glemnitz et al., 2011).
\end{abstract}


Sugarcane and sugar beet are two main sources of sugar production throughout the world (FAO 2017). Although in some country's other liquid sweeteners such as high fructose corn syrup is used but sugar is still used at higher levels (Fasahat et al., 2018). It has been anticipated that by 2024-25 the global sugar consumption will increase from 172.6 in 2018-19 to $214 \mathrm{Mt}$ (OECD 2015). Sugar beet has been considered as one of most important sugar crops in Iran which provides more than $60 \%$ of the produced sugar followed by sugarcane (FAO, 2017). In spite of the fact that most growers often apply wheat-sugar beet rotation in Iran, it is also recommended to integrate alfalfa and clover which increase soil organic matter and as a result improve soil structure (Götze et al., 2017). Selection of the proper crops integrated in the rotation and also the place of sugar beet is of importance. Cereals have high potential for weed suppression in the rotation. The presence of alfalfa in the rotation as well as increasing its period from three to six years not only improve sugar beet production but also dramatically decrease nematode population (Liebman and Dyck, 1993).

Based on the agronomical goals, sugar beet is integrated in the crop rotation as monoculture or a cropping interval of 2 years or more (Märländer et al., 2003; Götze et al., 2017). However, cropping intervals of less than 2 years are not recommended for sugar beet (Götze et al. 2017). In most studies, different crops such as winter wheat, winter barley, maize, potato, dry bean, pea, oat and timothy has been grown before sugar beet as preceding crops (Märländer et al., 2003; Buhre et al., 2014; Larney et al., 2016; Götze et al., 2017; Koch et al., 2018). Koch et al. (2018) found no dramatic yield loss in sugar beet as a consequence of shorter sugar beet cropping intervals and highlighted the influence of year and grower management on yield. Rychcik and Zawislak (2002) compared the effect of crop rotation vs. monoculture on root yield and qualitative traits of sugar beet. Results inferred the significant and positive influence of crop rotation. In a three-year study, Khorshidi et al. (2013) applied different rotations including fallow-onion-onion, fallow-sugar beet-sugar beet, onion-sugar beet-onion, sugar beet-onion-sugar beet as well as onion and sugar beet monoculture. Onion-sugar beet-onion and sugar beet-onion-sugar beet rotations resulted in significant increase in bulb weight and root yield in onion and sugar beet, respectively. However, sugar beet monoculture showed lower yield compared with other rotations. They have included that yield and yield components of onion were higher in rotation with sugar beet than its monoculture. Although sugar beet does not add too much residues into the soil but its deep root extension reduces nutrient loss from the soil surface and preserves nutrients for the next crop. In onion-sugar beet-onion rotation, it was observed that sugar beet root extension into the depth resulted in soil nutrient preservation for onion and played a significant role in increasing onion performance. In addition to above-mentioned advantages, no particular disease was observed in onion-sugar beet-onion rotation and chemical herbicides were also used at very low levels. The higher biomass produced by sugar beet reduces soil erosion, weed growth and nutrient leaching from the soil. In addition, it provides proper condition for soil microorganisms growth especially earthworms and improve soil organic matter (Khorshidi et al., 2013). Crookston et al. (1991) also reported that the presence of different crops in a rotation resulted in a higher yield than their monoculture.

In an experimental research area called Motahari Research Station (Iran), belonged to Sugar Beet Seed Institute in Karaj, Iran, sugar beet is integrated in the crop rotation every 6-7 years. This study aimed to evaluate the yield stability of sugar beet in two consecutive rotations including alfalfa-wheat-fallow-sugar beet.

\section{Materials and Methods}

The long-term field trials were conducted at the fields of Motahari Research Station in Karaj location $\left(35^{\circ} 59\right.$ ' N, 50 $\left.55^{\circ} \mathrm{E}\right)$ in Iran since 2009 . The soil texture of the experimental site was heavy to moderate classified as sedimentary soil. The $\mathrm{P}$ and $\mathrm{K}$ content in the soil (at 0-30 soil depth) ranged from 13.39 to 35.41 and 330.72 to $737.88 \mathrm{ppm}$, respectively (FAO/UNESCO,1990). The Soil pH was in the range of 7.33-8.54. Two crop rotations of alfalfa ( 4 years), winter wheat ( 1 year), fallow ( 1 year), and sugar beet ( 1 year) were cultivated with a cropping interval of 7 years for sugar beet in 2009 and 2010, respectively. Alfalfa was planted 
for forage consumption and was usually harvested four times a year. Rotations had completed two sequences. The average temperature and rainfall from 2009-2016 are summarized in Table 1.

Table 1. Distribution of temperature and rainfall in 2015 and 2016

\begin{tabular}{|c|c|c|c|c|c|c|c|c|}
\hline $\begin{array}{l}\text { Climatic } \\
\text { factors }\end{array}$ & & April & May & June & July & August & September & October \\
\hline \multicolumn{9}{|c|}{2015} \\
\hline \multirow[t]{2}{*}{ Temp $\left({ }^{\circ} \mathrm{C}\right)$} & Min. & 2.6 & 6.6 & 13.0 & 14.1 & 14.4 & 11.5 & 4.1 \\
\hline & Max. & 30.1 & 35.5 & 41.4 & 40.2 & 39.7 & 34.8 & 31.9 \\
\hline $\begin{array}{c}\text { Rainfall } \\
(\mathrm{mm})\end{array}$ & & 14.2 & 9.3 & 0.2 & 3.0 & 0.0 & 4.41 & 22.2 \\
\hline \multicolumn{9}{|c|}{2016} \\
\hline \multirow[t]{2}{*}{ Temp $\left({ }^{\circ} \mathrm{C}\right)$} & Min. & 0.5 & 8.2 & 10.3 & 14.9 & 15.3 & 9.0 & 4.3 \\
\hline & Max. & 31.6 & 35.1 & 39.1 & 40.7 & 38.1 & 35.7 & 29.2 \\
\hline $\begin{array}{c}\text { Rainfall } \\
(\mathrm{mm})\end{array}$ & & 51.6 & 12.6 & 0.0 & 0.0 & 0.0 & 0.0 & 2.4 \\
\hline
\end{tabular}

For sugar beet planting, seedbeds were prepared in early April and sowing date was performed on midApril 2015 and 2016 for first and second rotations, respectively. The plot size was $12 \mathrm{~m} 2$ (3 rows, 8-m-long with $50-\mathrm{cm}$ between rows) arranged in randomized complete block design with four replications. The distance between rows was $0.5 \mathrm{~m}$ and within rows $0.2 \mathrm{~m}$ apart. The experiments were managed according to local agronomic practices. Fields were visited routinely to prevent pest damages including Caradrina exigua, Agrotis ipsilon and Scrobipalpa ocellatella. For the whole field trial, the primary soil tillage was performed using mouldboard plough at 0-30 cm soil depth. Mineral nitrogen fertilization, and phosphate were applied at rate of 250 and $200 \mathrm{~kg} \mathrm{ha}^{-1}$, respectively on sugar beet, while on wheat the nitrogen rate was calculated based on the current year. No mineral nitrogen was applied for alfalfa. Cultivars included 'Arya,' 'Ekbatan', 'Motahar', 'Pars', 'Paya', 'SBSI004', 'Sharif, 'Shokoufa', and 'Torbat'. Only the crop rotations of the years 2009-15 and 2010-16 were used in this study since maize was inserted in rotation in other years.

At harvest, root samples were taken from the middle row of each plot for yield assessment. Roots were washed, weighed and sent to Sugar Laboratory at Sugar Beet Seed Institute in Karaj. Pulp samples were prepared and sucrose concentration as well as root impurities such as $\mathrm{K}, \mathrm{Na}$, and amino- $\mathrm{N}$ were determined using a Betalyser (Anton Paar, Germany) automatic beet laboratory system according to standard procedures (ICUMSA, 2009). White sugar yield as well as white sugar content were calculated according to Reinefeld et al. (1974)

To statistically evaluate the effect of the crop rotation field on root yield and quality traits, analysis of variance was performed using SAS software version 9.1 (SAS Institute, Cary, NC, USA). Prior to this, data were subjected to Bartlett's test for checking homogeneity of variance. Treatment means were compared using Duncan's multiple range test.

\section{Results}

In both rotations, all the parameters were influenced significantly by crop rotations except the sugar content and white sugar content in the first rotation and root yield and sugar yield in the second rotation (Table 2). Across both rotations, sugar beet root yield ranged from 56.5 to $83.2 \mathrm{t} \mathrm{ha}^{-1}$ in the first rotation and from 61.4 to $77.8 \mathrm{t} \mathrm{ha}^{-1}$ in the second rotation (Table 3). Averaged across rotations, the root yield was highest in the first rotation $\left(75.75 \mathrm{tha}^{-1}\right)$ compared with the second rotation $\left(71.15 \mathrm{t} \mathrm{ha}^{-1}\right)$ with a mean of $73.45 \mathrm{tha}^{-1}$ and no significant difference observed between rotations. 
Table 2. Probability values from F-test of fixed effects of first and second rotations on sugar beet cultivars performance and quality

\begin{tabular}{|c|c|c|}
\hline Parameter & First rotation & Second rotation \\
\hline Root yield & 0.0003 & 0.5114 \\
\hline Sugar yield & $<.0001$ & 0.0573 \\
\hline White sugar yield & $<.0001$ & 0.0014 \\
\hline Sugar content & 0.1739 & $<.0001$ \\
\hline White sugar content & 0.0540 & 0.0002 \\
\hline Alkalinity coefficient & 0.0005 & 0.0001 \\
\hline Extraction sugar coefficient & 0.0040 & 0.0012 \\
\hline Molasses sugar & 0.0009 & 0.0003 \\
\hline $\mathrm{Na}$ & 0.0003 & $<.0001$ \\
\hline $\mathrm{K}$ & 0.0004 & 0.0015 \\
\hline amino-N & 0.0002 & $<.0001$ \\
\hline
\end{tabular}

Averaged sugar yield across rotations was $8.37 \mathrm{t} \mathrm{ha}^{-1}$ with no significant difference between rotations (Table 2). White sugar yield averaged across rotations was lowest in second rotation $\left(4.21 \mathrm{t} \mathrm{ha}^{-1}\right)$ and highest in first rotation $\left(6.14 \mathrm{t} \mathrm{ha}^{-1}\right)$, with a mean of $5.18 \mathrm{t} \mathrm{ha}^{-1}$ (Table 3$)$. Differences in white sugar yield were primarily owing to differences in white sugar content and not root yield at both rotations. Sugar concentration averaged over rotation $s$ ranged from $11.47 \%$ in first rotation to $11.36 \%$ in second rotation. No significant difference was observed between two rotations (Table 3 ).

Table 3. Effects of rotation sequences on qualitative and quantitative characteristics of sugar beet cultivars

\begin{tabular}{|c|c|c|c|c|c|c|c|c|c|c|c|}
\hline \multirow{4}{*}{$\begin{array}{l}\text { Studied } \\
\text { levels of } \\
\text { treatments }\end{array}$} & \multicolumn{11}{|c|}{ Means $(\dagger)$} \\
\hline & \multirow{2}{*}{ RYキ } & \multirow{2}{*}{ SY } & \multirow{2}{*}{ WSY } & \multirow{2}{*}{$\mathrm{SC}$} & \multirow{2}{*}{ WSC } & \multirow{2}{*}{ ALC } & \multirow{2}{*}{ ESC } & \multirow{2}{*}{ MS } & \multicolumn{3}{|c|}{ Root impurities } \\
\hline & & & & & & & & & $\mathrm{Na}$ & $\mathrm{K}$ & $\mathrm{N}$ \\
\hline & $\left(\mathrm{t} \mathrm{ha}^{-1}\right)$ & $\left(\mathrm{t} \mathrm{ha}^{-1}\right)$ & $\left(\mathrm{tha}^{-1}\right)$ & (\%) & $(\%)$ & - & $(\%)$ & (\%) & \multicolumn{3}{|c|}{ (mmol $100 \mathrm{~g}^{-1}$ beet $)$} \\
\hline \multicolumn{12}{|l|}{ Rotation } \\
\hline First & $75.7 \mathrm{~ns}$ & $8.66 \mathrm{~ns}$ & $6.14 a$ & $11.47 \mathrm{~ns}$ & $8.14 \mathrm{a}$ & $1.71 \mathrm{~b}$ & $70.71 \mathrm{a}$ & $2.73 \mathrm{~b}$ & $4.12 \mathrm{~b}$ & $3.36 \mathrm{~b}$ & $4.73 a$ \\
\hline Second & 71.1 & 8.08 & $4.21 \mathrm{~b}$ & 11.36 & $5.91 \mathrm{~b}$ & $4.14 \mathrm{a}$ & $51.9 \mathrm{~b}$ & $4.76 a$ & $8.62 \mathrm{a}$ & $5.38 \mathrm{a}$ & $3.76 \mathrm{~b}$ \\
\hline \multicolumn{12}{|c|}{ First rotation } \\
\hline 'Arya' & $82.6 a$ & $9.39 \mathrm{ab}$ & $6.69 \mathrm{~b}$ & $11.44 \mathrm{ab}$ & $8.16 \mathrm{abc}$ & $1.72 \mathrm{~b}$ & $71.23 \mathrm{ab}$ & $2.68 \mathrm{bc}$ & $3.86 \mathrm{c}$ & $3.38 \mathrm{bc}$ & $4.48 \mathrm{bcd}$ \\
\hline 'Ekbatan' & $56.5 c$ & $6.51 \mathrm{~d}$ & $4.71 \mathrm{~d}$ & $11.59 \mathrm{ab}$ & $8.41 \mathrm{ab}$ & $0.98 \mathrm{c}$ & $72.3 \mathrm{ab}$ & $2.58 \mathrm{bc}$ & $3.54 \mathrm{c}$ & $3.01 \mathrm{~cd}$ & $6.89 a$ \\
\hline 'Motahar' & $79.4 \mathrm{ab}$ & $9.29 \mathrm{ab}$ & $6.58 b c$ & $11.72 \mathrm{ab}$ & $8.31 \mathrm{ab}$ & $1.39 \mathrm{bc}$ & $70.76 \mathrm{~b}$ & $2.8 \mathrm{~b}$ & $3.85 \mathrm{c}$ & $3.48 \mathrm{~b}$ & $5.43 \mathrm{~b}$ \\
\hline 'Pars' & $75.4 \mathrm{ab}$ & $8.67 b c$ & $6.25 b c$ & $11.5 \mathrm{ab}$ & $8.28 \mathrm{ab}$ & $1.54 \mathrm{~b}$ & $71.93 \mathrm{ab}$ & $2.61 b c$ & $3.93 b c$ & $3.27 \mathrm{bcd}$ & $4.83 b c$ \\
\hline 'Paya' & $83.2 \mathrm{a}$ & $8.93 b c$ & $5.8 \mathrm{c}$ & $10.75 \mathrm{~b}$ & $6.98 \mathrm{c}$ & $2.33 a$ & $64.6 c$ & $3.17 \mathrm{a}$ & $4.54 a b$ & $3.97 \mathrm{a}$ & $4.13 \mathrm{~cd}$ \\
\hline 'SBSI004' & $74.5 \mathrm{ab}$ & $8.18 \mathrm{c}$ & $5.72 \mathrm{c}$ & $11.02 \mathrm{~b}$ & $7.72 b c$ & $1.89 \mathrm{ab}$ & $96.92 \mathrm{~b}$ & $2.69 b c$ & $4.73 a$ & $2.89 \mathrm{~d}$ & $4.13 \mathrm{~cd}$ \\
\hline 'Sharif' & $72.9 \mathrm{~b}$ & $8.63 b c$ & $6.15 b c$ & $11.86 \mathrm{ab}$ & $8.45 \mathrm{ab}$ & $1.91 \mathrm{ab}$ & $71.15 \mathrm{ab}$ & $2.81 \mathrm{~b}$ & $4.64 a$ & $3.55 \mathrm{~b}$ & $4.21 \mathrm{~cd}$ \\
\hline 'Shokoufa' & $81.7 \mathrm{ab}$ & $10.12 \mathrm{a}$ & $7.57 \mathrm{a}$ & $12.38 \mathrm{a}$ & $9.27 \mathrm{a}$ & $1.36 \mathrm{bc}$ & $74.83 a$ & $2.51 \mathrm{c}$ & $3.3 c$ & $3.53 \mathrm{~b}$ & $5.05 b c$ \\
\hline 'Torbat' & $75.1 \mathrm{ab}$ & $8.25 c$ & $5.75 c$ & $11.0 \mathrm{~b}$ & $7.67 b c$ & $2.33 a$ & $69.72 b$ & $2.72 b c$ & $4.71 \mathrm{a}$ & $3.19 \mathrm{bcd}$ & $3.45 \mathrm{~d}$ \\
\hline \multicolumn{12}{|c|}{ Second rotation } \\
\hline 'Arya' & $74.5 \mathrm{ab}$ & $9.06 \mathrm{ab}$ & $5.27 \mathrm{ab}$ & $12.16 \mathrm{~b}$ & $7.08 \mathrm{ab}$ & $2.56 \mathrm{e}$ & $58.13 \mathrm{ab}$ & $4.22 \mathrm{~d}$ & $7.38 \mathrm{ef}$ & $5.35 \mathrm{~cd}$ & $4.95 \mathrm{~b}$ \\
\hline 'Ekbatan' & $70.6 \mathrm{ab}$ & $9.36 a$ & $6.01 \mathrm{a}$ & $13.26 \mathrm{a}$ & $8.51 \mathrm{a}$ & $3.01 \mathrm{de}$ & $64.25 a$ & $4.14 \mathrm{~d}$ & $6.61 \mathrm{f}$ & $5.25 \mathrm{cde}$ & $3.87 \mathrm{c}$ \\
\hline 'Motahar' & $65.7 \mathrm{ab}$ & $7.9 \mathrm{abc}$ & $4.22 b c$ & $12.06 \mathrm{~b}$ & $6.42 b c$ & $2.63 \mathrm{e}$ & $53.28 \mathrm{bc}$ & $5.03 a b c$ & $7.72 \mathrm{def}$ & $6.06 \mathrm{ab}$ & $6.13 a$ \\
\hline 'Pars' & $69.7 \mathrm{ab}$ & $7.31 b c$ & $3.82 \mathrm{c}$ & $10.47 \mathrm{~cd}$ & $5.44 \mathrm{~cd}$ & $5.59 \mathrm{ab}$ & $51.48 \mathrm{bc}$ & $4.43 \mathrm{~d}$ & $8.36 \mathrm{cde}$ & $5.07 \mathrm{cde}$ & $2.33 \mathrm{e}$ \\
\hline 'Paya' & $71.5 \mathrm{ab}$ & $7.68 \mathrm{abc}$ & $3.85 c$ & $10.71 \mathrm{~cd}$ & $5.29 \mathrm{~cd}$ & $4.22 \mathrm{bcd}$ & $54.16 \mathrm{bc}$ & $4.56 \mathrm{~cd}$ & $9.01 \mathrm{abc}$ & $4.66 \mathrm{e}$ & $2.97 \mathrm{cdec}$ \\
\hline 'SBSI004' & $77.8 \mathrm{a}$ & $8.92 \mathrm{ab}$ & $4.29 \mathrm{bc}$ & $11.5 \mathrm{bc}$ & $5.55 \mathrm{~cd}$ & $6.34 a$ & $48.02 \mathrm{~cd}$ & $5.59 \mathrm{a}$ & $10.24 a$ & $5.54 \mathrm{abc}$ & $2.81 \mathrm{de}$ \\
\hline 'Sharif' & $61.4 \mathrm{~b}$ & $6.62 \mathrm{c}$ & $3.13 c$ & $10.85 \mathrm{~cd}$ & $5.15 \mathrm{~cd}$ & $4.88 \mathrm{abc}$ & $47.09 \mathrm{~cd}$ & $5.09 \mathrm{abc}$ & $9.97 \mathrm{ab}$ & $4.86 \mathrm{de}$ & $3.33 \mathrm{cde}$ \\
\hline 'Shokoufa' & $75.2 \mathrm{ab}$ & $8.43 \mathrm{ab}$ & $4.12 b c$ & $11.2 \mathrm{bc}$ & $5.48 \mathrm{~cd}$ & $4.23 \mathrm{bcd}$ & $48.68 \mathrm{~cd}$ & $4.62 \mathrm{bcd}$ & $9.38 \mathrm{abc}$ & $5.45 \mathrm{bcd}$ & $3.59 \mathrm{~cd}$ \\
\hline 'Torbat' & $73.6 \mathrm{ab}$ & $7.4 \mathrm{bc}$ & $3.15 c$ & $10.02 \mathrm{~d}$ & $4.25 \mathrm{~d}$ & $3.83 \mathrm{cde}$ & $42.02 \mathrm{~d}$ & $5.17 \mathrm{ab}$ & $8.93 \mathrm{bcd}$ & $6.18 \mathrm{a}$ & $3.88 \mathrm{c}$ \\
\hline
\end{tabular}

$\dagger$ In any column, means with the same letter are not significantly different in 0.05 probability level.

‡RY=Root yield, SY=Sugar yield, WSY=White sugar yield, SC=Sugar content, WSC=White sugar content, ALC $=$ Alkalinity coefficient, $\mathrm{ESC}=$ Extraction sugar coefficient, $\mathrm{MS}=$ Molasses sugar, $\mathrm{Na}=$ Sodium, $\mathrm{K}=$ Potassium and $\mathrm{N}=$ Nitrogen 
Sugar loss to molasses was significantly higher in the second rotation (4.76\%) than the first rotation (2.73\%). In contrast to sugar loss to molasses, white sugar content was lowest in the second rotation $(5.91 \%)$ and highest in the first rotation $(8.14 \%)$ with a mean of $7.03 \%$. A significant $(\mathrm{P}<0.01)$ difference for white sugar content was observed among cultivars in the second rotation.

Mean impurity values were $4.25 \mathrm{mmol} 100 \mathrm{~g}^{-1}$ beet for a-amino- $\mathrm{N}, 6.37 \mathrm{mmol} 100 \mathrm{~g}^{-1}$ beet for $\mathrm{Na}$, and $4.38 \mathrm{mmol} 100 \mathrm{~g}^{-1}$ beet for $\mathrm{K}$ across both rotations. Significant rotation effect $(\mathrm{P}<0.01)$ was occurred for impurities. However, $\mathrm{Na}$ and $\mathrm{K}$ content was higher in second rotation compared with first rotation. In the second rotation, the alkalinity $(4.14)$ was significantly $(\mathrm{P}<0.01)$ higher than first rotation $(1.71)$. In the second rotation, the extraction sugar coefficient was significantly $(\mathrm{P}<0.01)$ lower $(51.9 \%)$ than the first rotation (70.71\%).

\section{Discussion}

It has been documented that a preceding crop can influence the yield and agronomic efficiency of the subsequent crops (Kopke and Nemecek, 2010; Hemayati et al., 2017; Koch et al., 2018). In addition, frequent cultivation of a crop with similar management practices has negative impact on soil quality and as a consequence increase in weed and pest population as well as the disease widespread (Bennett et al., 2011; Stein and Steinmann, 2018). In this study, the conventional rotation including legume and cereal as a preceding crop of sugar beet was evaluated for the first time in Karaj region. In contrast to Nemecek et al. (2008) reported that the risk of N-leaching of crop rotation can be increased by legumes' monoculture, 4-year cultivation of alfalfa equilibrated this problem. Jacobs et al. (2018) has also cultivated mustard as a catch crop between grain pea and sugar beet to reduce the risk of $N$-leaching.

In a 12-year study conducted by Larney et al. (2016), 4 to 6-year rotations including dry bean, potato, spring wheat, oat and timothy were compared. Until the seventh year of their study, no significant effect of rotation on root yield was occurred which illustrates that longer-term commitments are required in rotation studies for evidence of significant response. The yield data reported in the present study were higher than Larney et al. (2016) study which may be related to the integration of timothy after alfalfa in their study. Increased $\mathrm{N}$ mineralisation from alfalfa residues during the sugar beet growing season can result in late-season $\mathrm{N}$ uptake and as a consequence lower white sugar yield. Therefore, growing sugar beet after forage legume such as alfalfa is often discouraged (Lamb and Sims, 2011). Long-term field trial studies performed in Etzdorf in Germany has shown that the integration of alfalfa into crop rotation system may results in yield increase owing to its phytosanitary effect as well as ability to improve soil structure (Duda and Liste, 1991; Deumelandt et al., 2010).

In the present study we have applied a $16 \%$ cropping concentration of sugar beet which illustrates the wide cropping interval. Götze et al. (2017) reported an increase in sugar beet root yield and white sugar yield with increase in the cropping interval; however, they have applied a 20-100\% cropping concentration of sugar beet. They have also reported lower root yield and sugar content for sugar beet monoculture as well as crop rotation fields with no integration of alfalfa. Similarly, Rychcik and Zawislak (2002) reported $0.7 \%$ higher sucrose content in crop rotation than sugar beet monoculture. In both rotations, cultivars Arya and Shokoufa which are new developed cultivars showed high root yield and sugar yield confirming that the negative relationship between root yield and sugar yield is not as tightly as it was before (Fasahat et al., 2018). Although a bit higher average sugar yield was observed in the first rotation but no significant difference was observed between both rotations. In a survey by Koch et al. (2018), a slight increase in sugar yield was observed with increasing cropping interval from 2 to 3 years in east and West regions of Germany.

Since white sugar yield is calculated based on integration of root yield and white sugar content, no surprisingly, the highest root yield $\left(75.7 \mathrm{t} \mathrm{ha}^{-1}\right)$ and white sugar content $(8.14 \%)$ was observed in the first rotation. In Larney et al. (2016) study, a lower white sugar yield was connected with sugar beet growing after 
timothy in the rotation. Integrating alfalfa in sugar beet rotation has a positive impact on root yield and white sugar yield stability even for a cropping interval of one year (Götze et al., 2017). Rychcik and Zawislak (2002) reported average white sugar yield of $7.89 \mathrm{t}$ ha-1 in 6-fields rotation. Larney et al. (2016) reported higher white sugar yield (6.06-13.5 $\left.\mathrm{t} \mathrm{ha}^{-1}\right)$ range than this study. Different factors such as soil quality, mineral fertilization as well as climate condition during the vegetation period can influence the molasses sugar content in root (Rychcik and Zawislak, 2002). The high molasses content in the second crop rotation was attributable to the high potassium and sodium content which also resulted in lower white sugar yield compared with the first rotation. Larney et al. (2016) attributed the difference in rotation frequencies to the rainfall amount in different years. The present results are in agreement with those obtained by Rychcik and Zawislak (2002), who found less potassium and amino- $\mathrm{N}$ and more sodium in the root pulp of sugar beets from crop rotation. The advantage of legume integration into the rotation in increasing $\mathrm{N}$ - and energy efficiency of crop rotation has been reported in previous studies (Franzluebbers and Francis, 1995; Nemecek et al., 2008; Jacobs et al., 2018).

\section{Conclusions}

In the present study we have evaluated the effect of rotation frequencies on yield and quality characteristics of sugar beet. Results showed that our new developed cultivars namely 'Arya' and 'Shokoufa' showed higher root yield and sugar yield compared with other cultivars. In general, the alfalfa-wheat-fallowsugar beet rotation had positive impact on sugar beet performance as well as low incidence of disease occurrence. This rotation is recommended to be applied by the growers which has both economic and agronomic advantages.

\section{Authors' Contributions}

PF conceived the idea of the study and drafted the initial manuscript. MRO and $\mathrm{MH}$ conducted the trial, scrutinized and corrected the manuscript.

All authors read and approved the final manuscript.

\section{Acknowledgements}

This research received no specific grant from any funding agency in the public, commercial, or not-forprofit sectors.

\section{Conflict of Interests}

The authors declare that there are no conflicts of interest related to this article.

\section{References}

Bennett AJ, Bending GD, Chandler D, Hilton S, Mills P (2011). Meeting the demand for crop production: the challenge of yield decline in crops grown in short rotations. Biological Reviews 87:51-72. https://doi.org/10.1111/j.1469$185 X .2011 .00184 . X$

Buhre C, Apfelbeck R, Hesse F, van Look M, Mielke C, Ladewig E (2014). Survey on production technology - regional differences in sugar beet production. Sugar Industry 139:40-47. 
Crookston RK, Kurle JE, Copeland PJ, Ford JH, Lueschen WE (1991). Rotational cropping sequence affects yield of corn and soybean. Agronomy Journal 83(1):108-113. https://doi.org/10.2134/agronj1991.00021962008300010026x

Davis AS, Hill JD, Chase CA, Johanns AM, Liebman M (2012). Increasing cropping system diversity balances productivity, profitability and environmental health. PloS One 7(10):e47149. https://doi.org/10.1371/journal.pone.0047149

Deumelandt P, Hofmann B, Christen O (2010). Effect of various rotations and fallow periods on soil quality parameters and yield in the sugar beet rotation experiment Etzdorf. Achieves of Agronomy and Soil Science 56:393-404.

Duda A, Liste HJ (1991). Measures of crop rotation for limiting the damage caused by the beet cyst nematode. Die Bodenkultur 42:253-260.

FAO (2017). Retrieved 2018 December 17 from http://www.fao.org/faostat/en/\#data/FBS

FAO/UNESCO (1990) Soil map of the world. Revised legend. World Soil Resources Report pp 60.

Fasahat P, Aghaeezadeh M, Jabbari L, Hemayati SS, Townson P (2018). Sucrose accumulation in sugar beet: from fodder beet selection to genomic selection. Sugar Tech 20(6):635-644. https://doi.org/10.1007/s12355-018-0617-Z

Franzluebbers AJ, Francis CA (1995). Energy output:input ratio of maize and sorghum management systems in eastern Nebraska. Agriculture, Ecosystems \& Environment 53:271-278. https://doi.org/10.1016/0167-8809(94)00568$Y$

Glemnitz M, Wurbs A, Roth R (2011). Derivation of regional crop sequences as an indicator for potential GMO dispersal on large spatial scales. Ecological Indicators 11:964-973. https://doi.org/10.1016/j.ecolind.2009.03.005

Götze P, Rücknagel J, Wensch-Dorendorf M, Märländer B, Christen O (2017). Crop rotation effects on yield, technological quality and yield stability of sugar beet after 45 trial years. European Journal of Agronomy 82:50-59. https://doi.org/10.1016/j.eja.2016.10.003

Hemayati SS, Akbar MRJE, Ghaemi AR, Fasahat P (2017). Efficiency of white mustard and oilseed radish trap plants against sugar beet cyst nematode. Applied Soil Ecology 119:192-196. https://doi.org/10.1016/j.apsoil.2017.06.017

ICUMSA (2009). International commission for uniform methods of sugar analysis. Methods Book. Bartens, Berlin.

Jacobs A, Koch HJ, Märländer B (2018). Preceding crops influence agronomic efficiency in sugar beet cultivation. Agronomy for Sustainable Development 38(1):5. https://doi.org/10.1007/s13593-017-0469-Z

Khorshidi MB, Abedi MS, Mohammadi-Poor M, Nasseri A, Bybordi A (2013). Response of onion to rotation with sugar beet in Azarbaijan region. Agricultural Science and Sustainable Production 23(4):215-226. (in Persian)

Koch HJ, Trimpler K, Jacobs A, Stockfisch N (2018). Crop rotational effects on yield formation in current sugar beet production-results from a farm survey and field trials. Frontiers in Plant Science 9:231. https://doi.org/10.3389/fpls.2018.00231

Kopke U, Nemecek T (2010). Ecological services of faba bean. Field Crops Research115:217-233. https://doi.org/10.1016/j.fcr.2009.10.012

Larney FJ, Nitschelm JJ, Regitnig PJ, Pearson DC, Blackshaw RE, Lupwayi NZ (2016). Sugar beet response to rotation and conservation management in a 12-year irrigated study in southern Alberta. Canadian Journal of Plant Science 96:776-789. https://doi.org/10.1139/cjps-2016-0005

Lamb JA, Sims AL (2011). Fertilizing sugar beet in southern Minnesota. Retrieved 2015 November 27 from http://www.extension.umn.edu/agriculture/nutrient-management/nutrient-lime guidelines/docs/fertilizingsugar-beet-insouthern-mn.pdf

Liebman M, Dyck E (1993). Crop rotation and intercropping strategies for weed management. Ecological Applications 3(1):92-122. https://doi.org/10.2307/1941795

Märländer B, Hoffmann CM, Koch H-J, Ladewig E, Merkes R, Petersen J, Stockfisch N (2003). Environmental situation and yield performance of the sugar beet crop in Germany: heading for sustainable development. Journal of Agronomy and Crop Science 189:201-226. https://doi.org/10.1046/j.1439-037X.2003.00035.x

Nemecek T, von Richthofen J-S, Dubois G, Casta P, Charles R, Pahl H (2008). Environmental impacts of introducing grain legumes into European crop rotations. European Journal of Agronomy 28:380-393. https://doi.org/10.1016/j.eja.2007.11.004

OECD/FAO (2015). OECD-FAO Agricultural Outlook 2015. OECD Publishing, Paris. http://dx.doi.org/10.1787/agr_outlook-2015-en

Reinefeld E, Emmerich A, Baumgarten G, Winner C, Beiss U (1974). Zur Voraussage des Melassezuckers aus Rubenanalyssen. Zucker 27:2-15. 
Rychcik B, Zawislak K (2002). Yields and root technological quality of sugar beet grown in crop rotation and long-term monoculture. Rostlinna Vyroba 48:458-462. https://doi.org/10.17221/4395-PSE

Stein S, Steinmann HH (2018). Identifying crop rotation practice by the typification of crop sequence patterns for arable farming systems-A case study from Central Europe. European Journal of Agronomy 92:30-40. https://doi.org/10.1016/j.eja.2017.09.010

van Zanten BT, Verburg PH, Espinosa M, Gomez-y-Paloma S, Galimberti G, Kantelhardt J, ... Raggi M (2014). European agricultural landscapes, common agricultural policy and ecosystem services: a review. Agronomy for Sustainable Development 34:309-325. https://doi.org/10.1007/s13593-013-0183-4
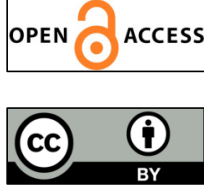

The journal offers free, immediate, and unrestricted access to peer-reviewed research and scholarly work. Users are allowed to read, download, copy, distribute, print, search, or link to the full texts of the articles, or use them for any other lawful purpose, without asking prior permission from the publisher or the author.

License - Articles published in Notulae Scientia Biologicae are Open-Access, distributed under the terms and conditions of the Creative Commons Attribution (CC BY 4.0) License.

(c) Articles by the authors; SHST, Cluj-Napoca, Romania. The journal allows the author(s) to hold the copyright/to retain publishing rights without restriction. 